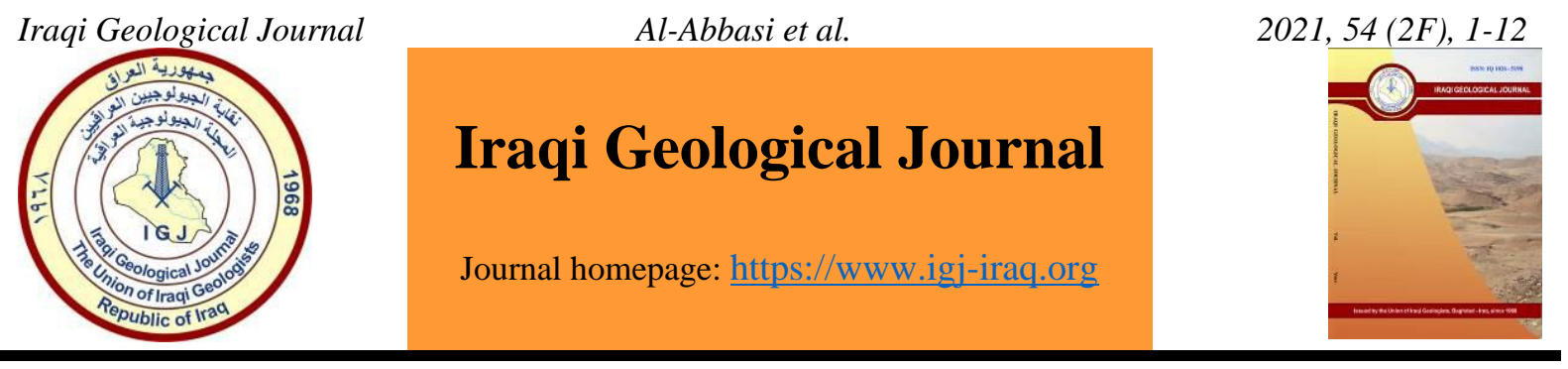

\title{
Biostratigraphy and Facies Analysis of Upper Valanginian-Upper Hauterivian (Sarmord Formation) in Maten Anticline, Northern Iraq
}

\author{
Mohammed W. Al-Abbasi ${ }^{1, *}$, Majid M. Al-Mutwali ${ }^{2}$ and Nabil Y. Al-Banna ${ }^{2}$ \\ 1 College of Environmental Science and Technologies, University of Mosul, Iraq \\ 2 Collage of Petroleum and Mining Engineering, University of Mosul, Iraq \\ * Correspondence: mws3000@uomosul.edu.iq
}

Received: 18 February 2021; Accepted:5 October 2021; Published: 31 December 2021

\begin{abstract}
Biostratigraphical and sedimentological study of the Sarmord Formation (Upper Valanginian - Upper Hauterivian) at the southern limb of Maten anticline is conducted within a well-exposed section. The formation is composed of marl, marly limestone, limestone, and dolostone, which yielded moderately diversified benthonic foraminiferal fauna, green algae, echinoderms, gastropods and some bioclast. The stratigraphic distribution of the benthonic species permits the recognition of two well-defined biozones. These are Everticyclammina kelleri Assemblage Zone, which represents the Late Valanginian age and Pseudocyclammina lituus Assemblage Zone, indicating Hauterivian age. These larger benthonic foraminiferal biozones are correlated with other zonal schemes inside and outside of Iraq, which indicates that the age of the Sarmord Formation in Maten anticline extends from Late Valanginian to Late Hauterivian age. The Sarmord Formation in the studied section is composed of limestone, dolomite, marl and conglomerate lithofacies types. Limestone lithofacies is represented by lime wackestone microfacies. According to the characteristic features of these facies, the depositional environments extend from tidal flat to shallow open marine environments.
\end{abstract}

Keywords: Sarmord Formation; Biostratigraphy; Benthonic Foraminifera; Maten anticline; Iraq

\section{Introduction}

The Sarmord Formation was firstly described by Wetzel in Bellen et al. (1959) from the Surdash anticline, Sulaimaniyah District, north-eastern Iraq. The type section is made up of two different parts, the lower $(273 \mathrm{~m})$ was described from the section in the course of the stream, which flows northwards through Sargelu village, whereas, the upper $(182 \mathrm{~m})$ of the formation was exposed in the Qamchuqa Gorge section. Lithologically, the Sarmord Formation consists of brown and bluish marls, buff weathering, with alteration of marly neritic limestones. Previous stratigraphic studies are demonstrated that the Sarmord Formation belongs to Valanginian-Aptian age for the formation (Bellen et al., 1959). Chatton and Hart (1960) divided the formation into the Lower, Middle, and Upper Sarmord Formation. Ditmar (1971) assigned a Tithonian-Berriasian age to the Lower Sarmord, a Valanginian -Aptian age to the Middle Sarmord, and an Albian age to the Upper Sarmord. Then, Buday (1980) combined the Lower and Upper parts into the Lower Sarmord. Jassim and Buday (2006a) agreed on this division and considered the formation as two parts, the Lower Sarmord Formation (Latest Berriasian - Aptian) and

DOI: $10.46717 /$ igj.54.2F.1ms-2021-12-18 
the Upper Sarmord Formation (Albian). The study of Ahmed et al. (2016) for the basin evolution model during Cretaceous in the northeastern Arabian plate concluded that During the Berriasian to Barremian the Kurdistan region was covered by the carbonates of the Balambo and Sarmord formations, while in the east and southeast of Kurdistan region, the neritic Sarmord Formation gradationally and laterally passes to the basinal facies of the Balambo Formation (Karim et al., 2021). Al-Abbasi (2017) studied the sedimentary facies of Sarmord Formation with other formations in northern Iraq and indicated that the formation was deposited in Tidal flat to shallow open marine environment. On the other hand, Mamaseni et al. (2018) studied the petrophysical properties of the Sarmord Formation in the Shaikhan Oilfield/Northern Iraq, and pointed out that it is composed of limestone and dolomitic limestone. The average clay content is about $19 \%$, and reveals poor to fair porosity except some beds in the upper part of the formation that have good porosity.

According to Jassim and Buday (2006a), the Lower Sarmord Formation occurred in the High folded and Foothill zones of NE Iraq, while the upper Sarmord Formation just appeared in foothill zone as the subsurface between Kirkuk in the East and Mosul in the West. Moreover, the type locality of the formation does not include the Albian sediments, which means that the type section comprises the lower Sarmord only (Fig. 1).

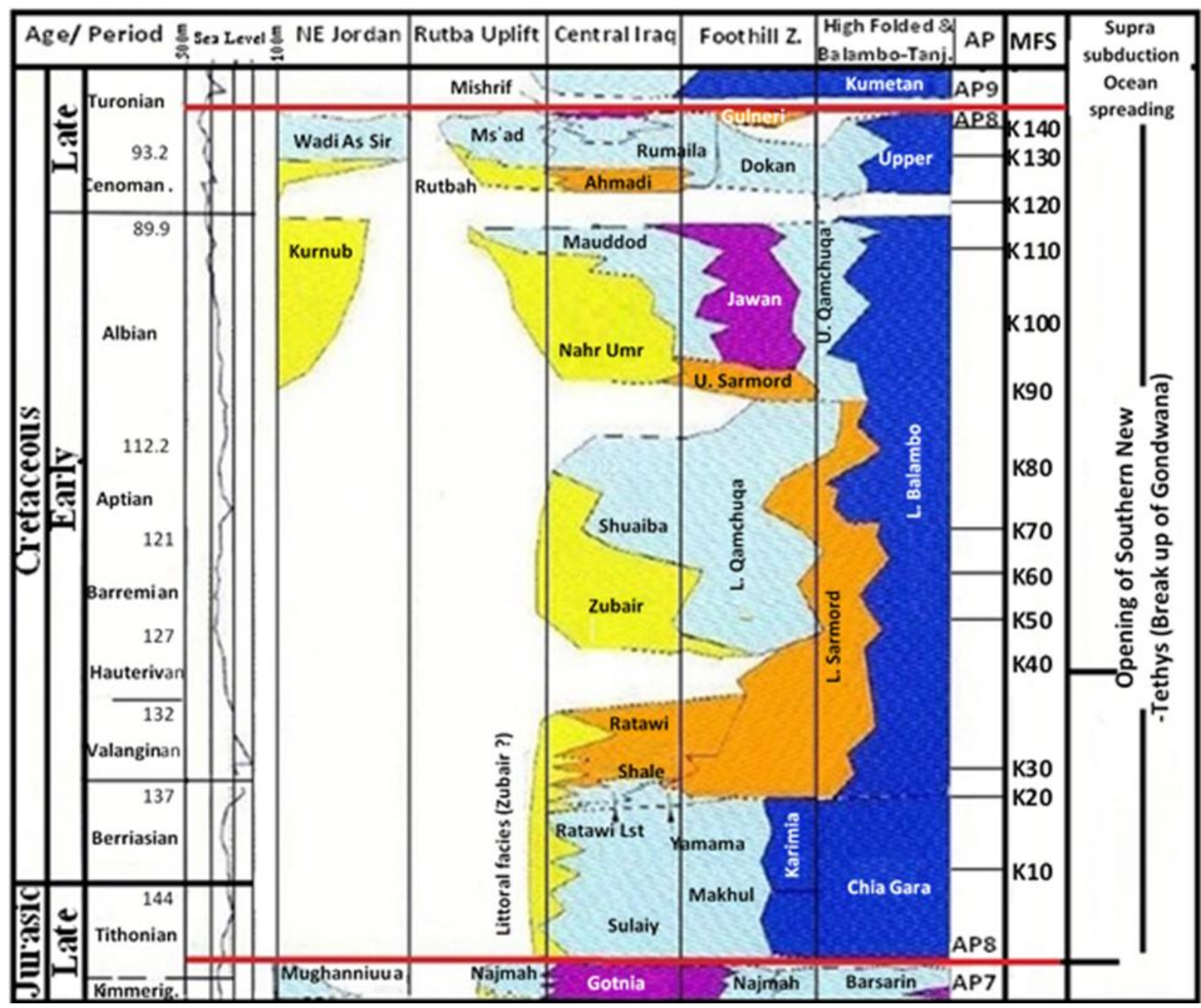

Fig. 1. Stratigraphic correlation of megasequence AP8 (Jassim and Buday, 2006a)

Since the surface studies of the Sarmord Formation are rather few, the current study aims to recognize the fossil assemblages, especially benthonic foraminiferal species, and establish their 
biostratigraphic zones for age determination, as well as facies analysis and paleoenvironmental reconstruction.

\section{Field Description of the Studied Section}

The studied section is located on the southern limb of Maten anticline, about $3 \mathrm{~km}$ northeast of Solaf Resort (Fig. 2). The midpoint of the section is at $37^{\circ} 33^{\prime} 00^{\prime \prime}$ Latitude and $43^{\circ} 30^{\prime} 00^{\prime \prime}$ Longitude within the High Folded Zone of the Unstable Shelf.

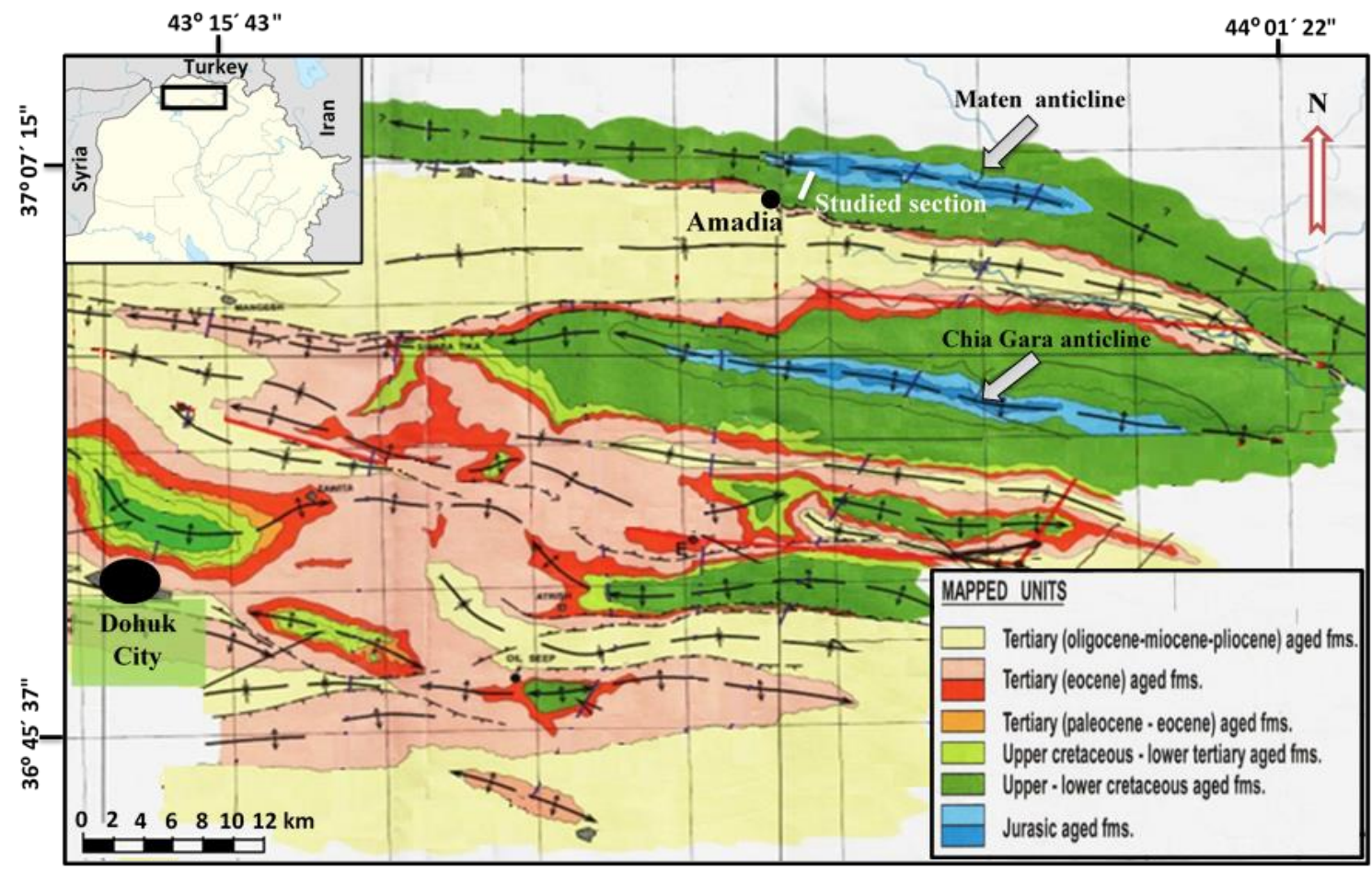

Fig. 2. Tectonic and location map of the studied section, North Iraq (Merty energy company, 2004)

The Sarmord Formation is about $67 \mathrm{~m}$ thick (Fig. 3). The lower contact is unconformable with the Chia Gara Formation (Fig. 4), in terms of the appearance of a succession of three pale yellow conglomerate beds (Fig. 5). The lower part of the formation consists of a repetition of pale-yellow bioclastic limestone (20-150 cm thick), interbedded with thin gray marl beds (10-20 cm thick) (Fig. 6), with some pale brown dolostone beds (30-70 cm thick for each bed). The same lithology is repeated in the upper part of the formation, with absence of dolostone beds, and presence of many marl beds, and a few limestone and breccia (Fig. 7). The upper most part is characterized by thick marl bed $(6 \mathrm{~m})$ interbedded with pale-brown limestone beds $(30 \mathrm{~cm}$ thick). The upper boundary of the formation with the Qamchuqa Formation (Early Barremian) is sharp, located at the top of the last marl bed of the Sarmord Formation and the base of massive limestone bed of Qamchuqa Formation, (Fig. 4).

\section{Materials and Methods}

Thirty-five samples have been collected from the studied section. and taken at a spacing ranging from $50 \mathrm{~cm}$ in marl, conglomerate, and breccia beds to $2 \mathrm{~m}$ in the beds of limestone and dolostone. The current study is based on the examination of thin sections, prepared in the Department of Earth Sciences workshop at Mosul university and about 30 thin sections were made to carry out a biostratigraphy and facies analysis. 


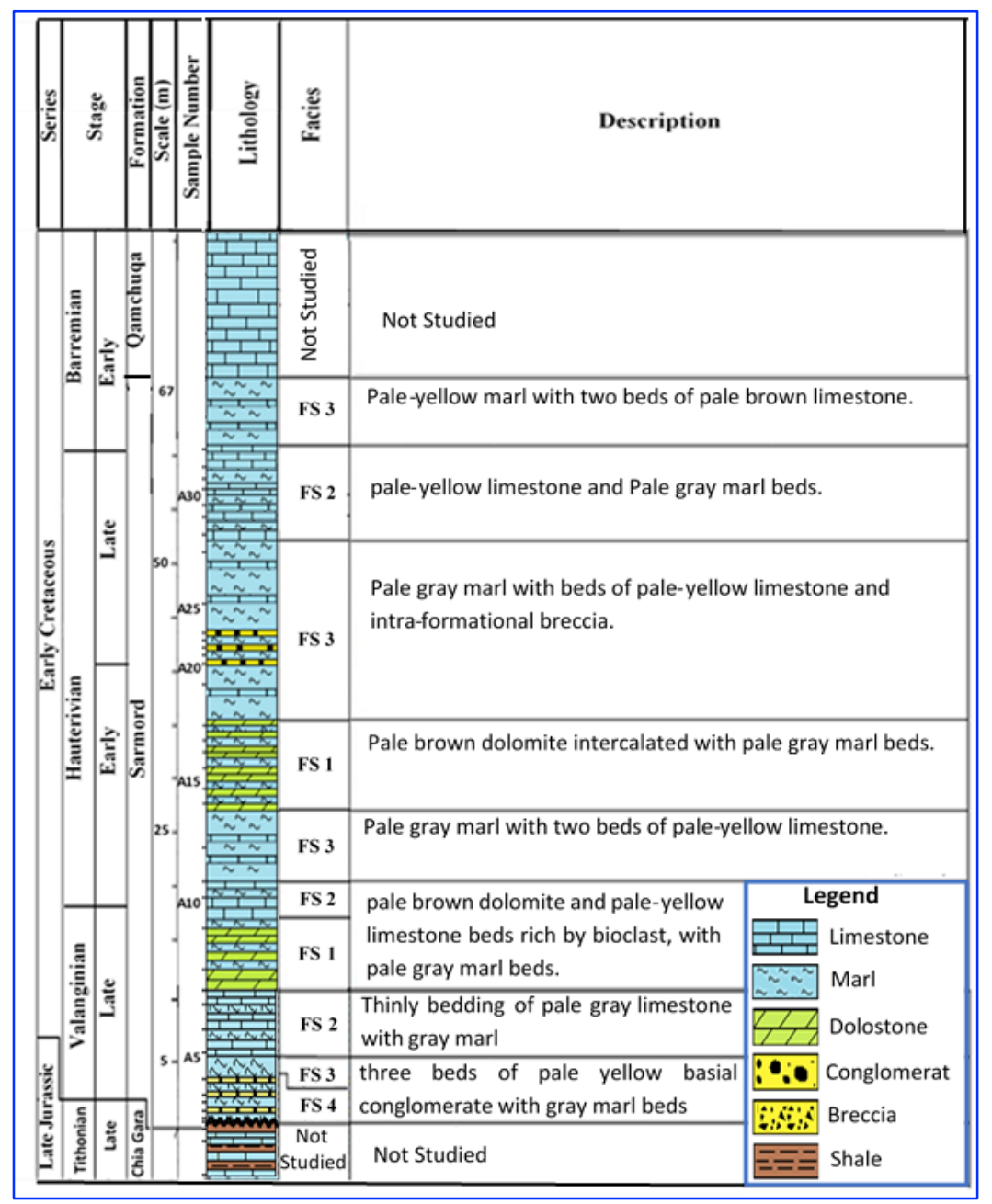

Fig. 3. Stratigraphic log explains the description of facies types of the Sarmord Formation in the studied area

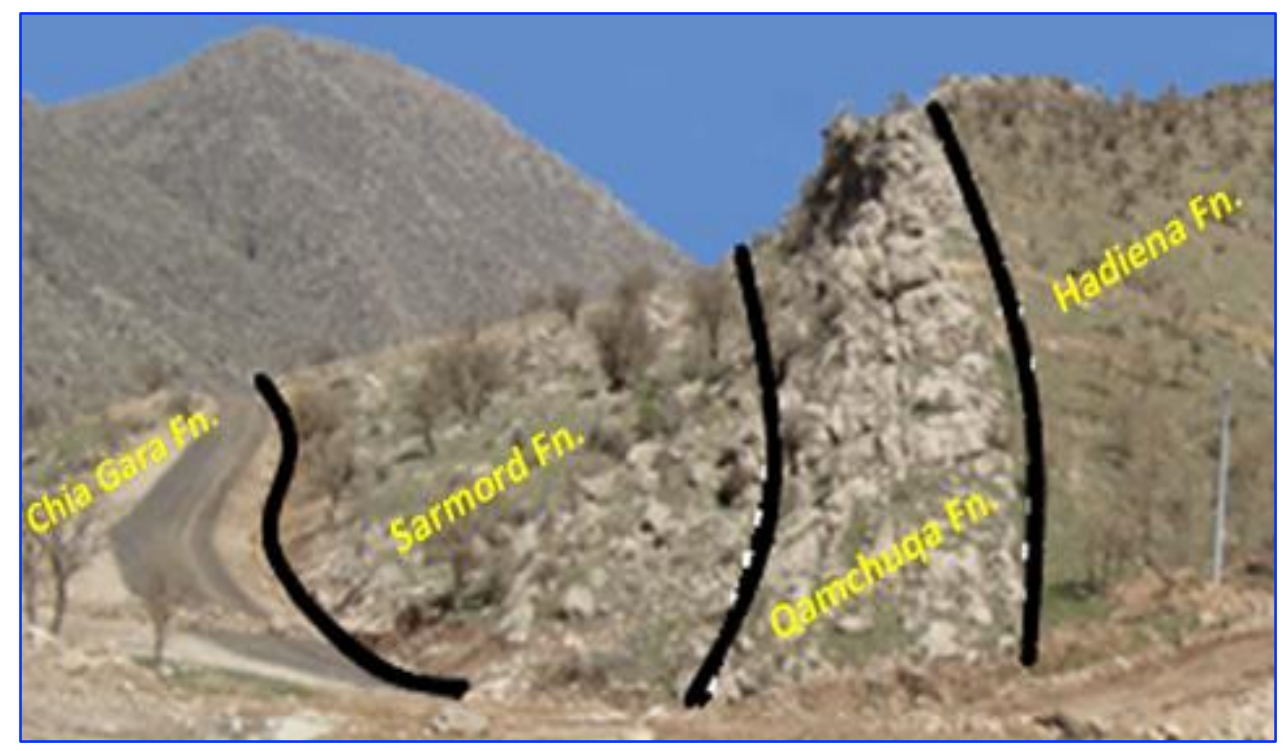

Fig. 4. Field view of the lower and upper contact of the Sarmord Formation at the studied area 


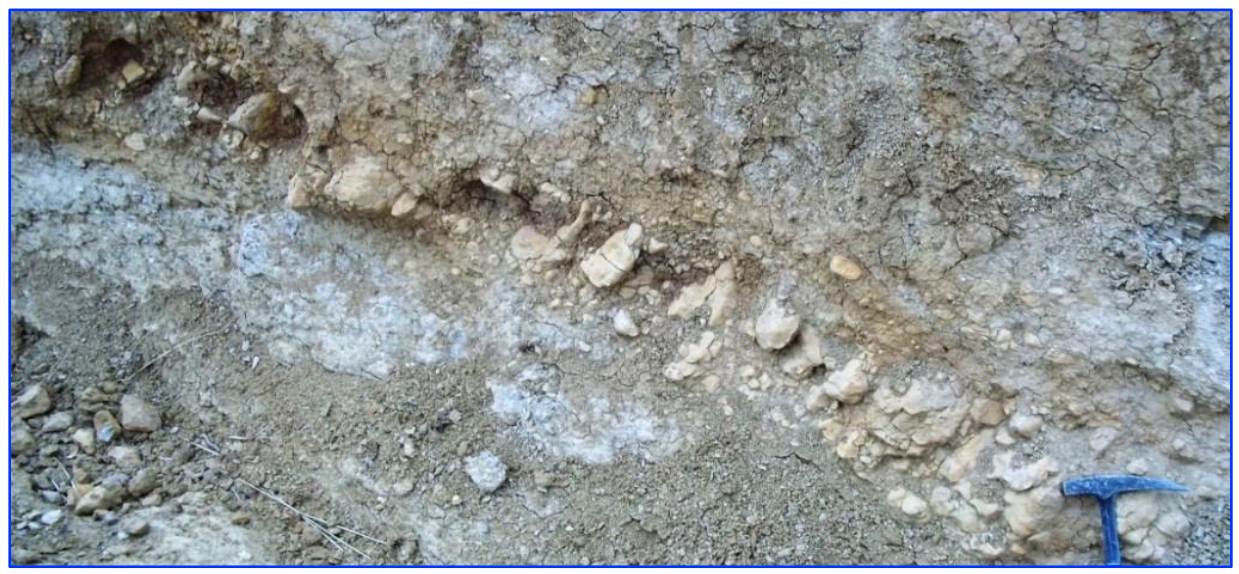

Fig. 5. One of the basal Conglomerate beds in the lower part of the Sarmord Formation
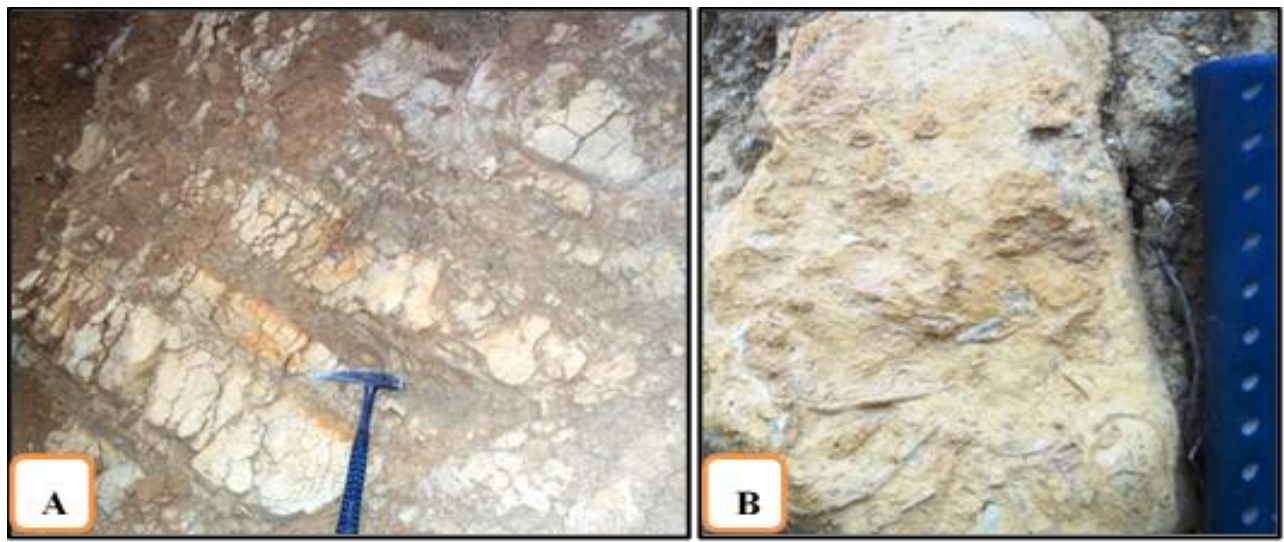

Fig. 6. A). Pale-yellow highly fractured and fragmented limestone interspersed with marl at the lower part of the Sarmord Formation; B). An enlarged picture of a limestone bed showing the Mollusca bioclast
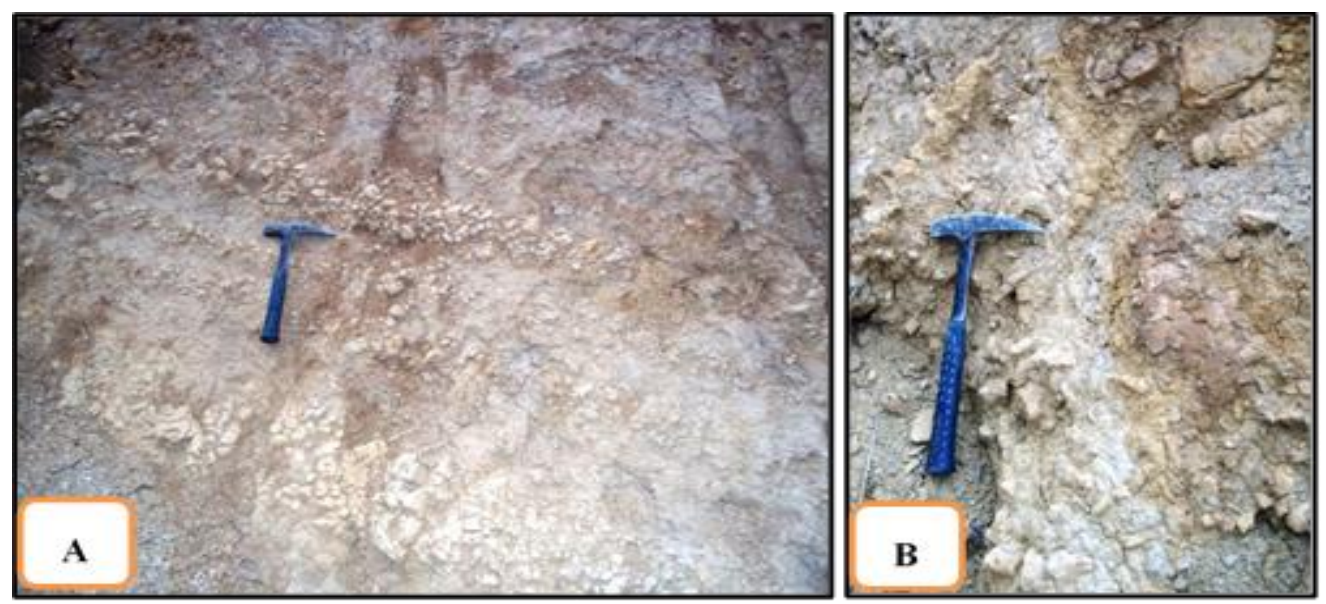

Fig. 7. A). Intraformational breccia bed in the upper part of the formation; B). A zoomed photo of the brecciated limestone 


\section{Facies Analysis}

The Sarmord Formation is classified into four lithofacies, denoted as FS1 to FS4, for which the sedimentological and paleontological clues are used to determine the depositional environment, these facies are:

\subsection{Fossiliferous Lime Wackestone Microfacies FS1}

The allochems percentage of this microfacies ranges between $15-50 \%$ of the total facies content. The facies consist primarily of benthonic foraminifera (Everticyclammina kelleri, Everticyclammina greigi, Everticyclammina sp., Pseudocyclammina lituus, Pseudocyclammina sp., Istriloculina eliptica, Istriloculina sp., Lenticulina sp., Cuneolina sp., and Scythiloculina sp.), with few echinoderm spines and green algae (Fig. 8). The effect of the dissolution process is obvious at some levels of this facies resulting in the channel's porosity.
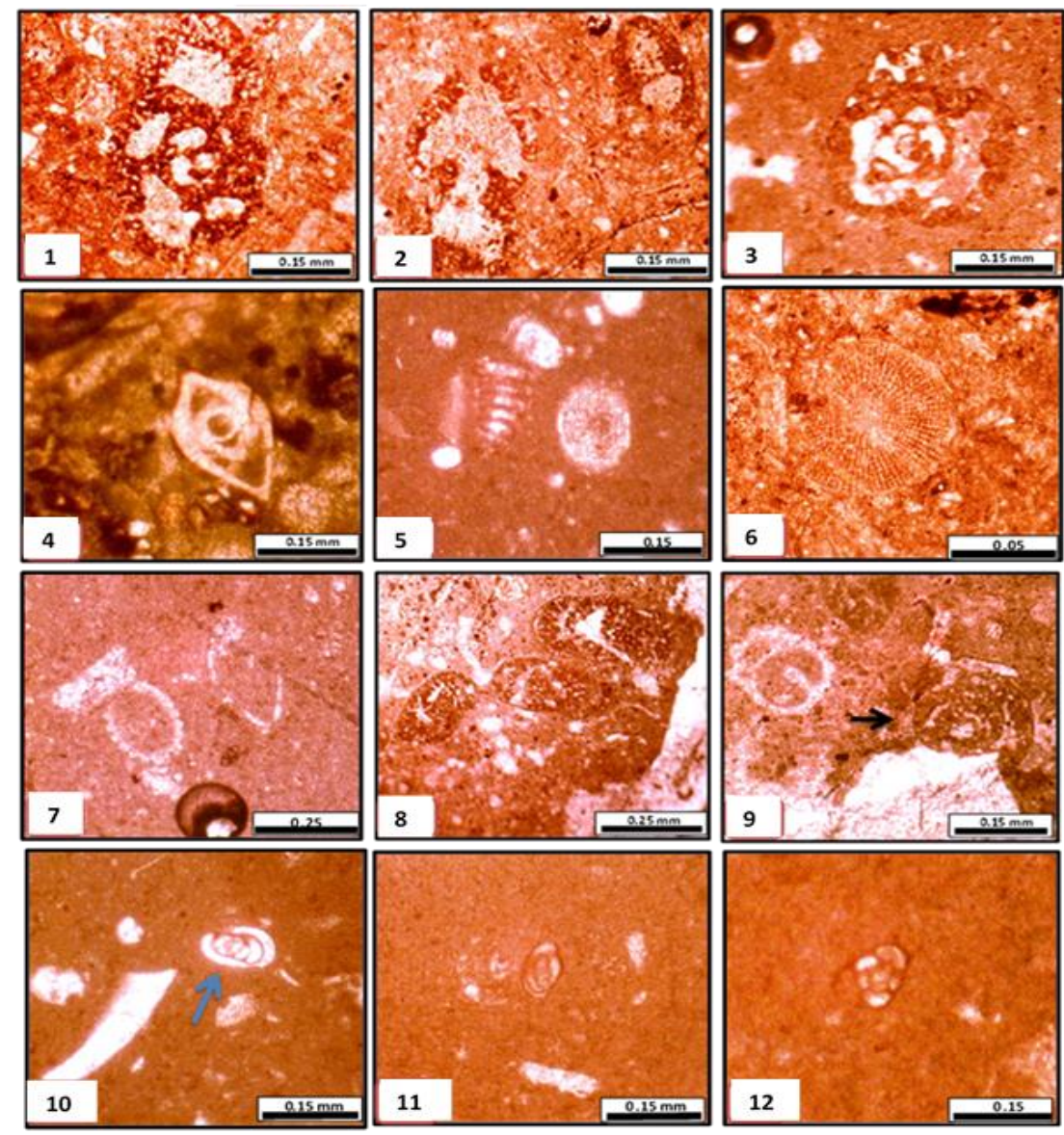

Fig. 8. Associated fauna that were recorded in the current study. 1: Everticyclammina kelleri (Henson, 1948), Fossiliferous lime wackestone facies FS2, sample n. A5. 2: Everticyclammina greigi (Henson, 1948), Fossiliferous lime wackestone facies FS2, sample n. A5. 3: Everticyclammina sp., Fossiliferous lime wackestone facies FS2, sample n. A7. 4: Lenticulina sp., Fossiliferous lime wackestone facies FS2, sample n. A32. 5: Cuneolina sp., Fossiliferous lime wackestone facies FS2, sample n. A6. 6: Cross section in a spine of echinoderm, Fossiliferous lime wackestone facies FS2, sample n. A5. 7: Green algae, Fossiliferous lime wackestone facies FS2, sample n. A9. 8: Pseudocyclammina lituus Yokoyama, 1890, Fossiliferous lime wackestone facies FS2, sample n. A11. 9: Pseudocyclammina sp., Fossiliferous lime wackestone facies FS2, sample n. A33. 10: Istriloculina eliptica, Fossiliferous lime wackestone facies FS2, sample n. A11. 11: Istriloculina sp., Fossiliferous lime wackestone facies FS2, sample n. A29. 12: Scythiloculina sp., Fossiliferous lime wackestone facies FS2, sample n. A30. 


\subsection{Dolomite Lithofacies FS2}

This microfacies consists of pale brown dolomite beds, intercalated with pale gray marl beds. The microscopic results showed the scarcity of allochems, except some levels of this facies, which have a few destroyed shells (less than 5\% of the total facies content) due to the dolomitization process. The facies was affected at most levels by strong dolomitization process, producing an aphanotopic texture, with fenestral porosity, that is empty or filled with crystals of secondary gypsum (Fig. 9-1), in addition to a little micro suture mosaic texture (Fig. 9).

\subsection{Marl Lithofacies FS3}

The marl facies (Fig. 10) is friable and attains pale blue to pale to dark yellow color. It contains iron oxides in some beds giving dark color. These beds of marl are interbedded with limestone and intraformational breccias. Each bed attains $0.4 \mathrm{~m}$ in thickness and contains bivalvia bioclast and some gastropod shells (Fig. 10).

\subsection{Conglomerate Lithofacies FS4}

This facies consists of three pale yellow beds of conglomerate (Fig. 4), intercalated with pale gray marl. The conglomerate beds embrace carbonate pebbles ranging in size between $(1-3 \mathrm{~cm})$ with poor sorting and rounded to semi-rounded shape, they are characterized by random distribution among carbonate matrix.
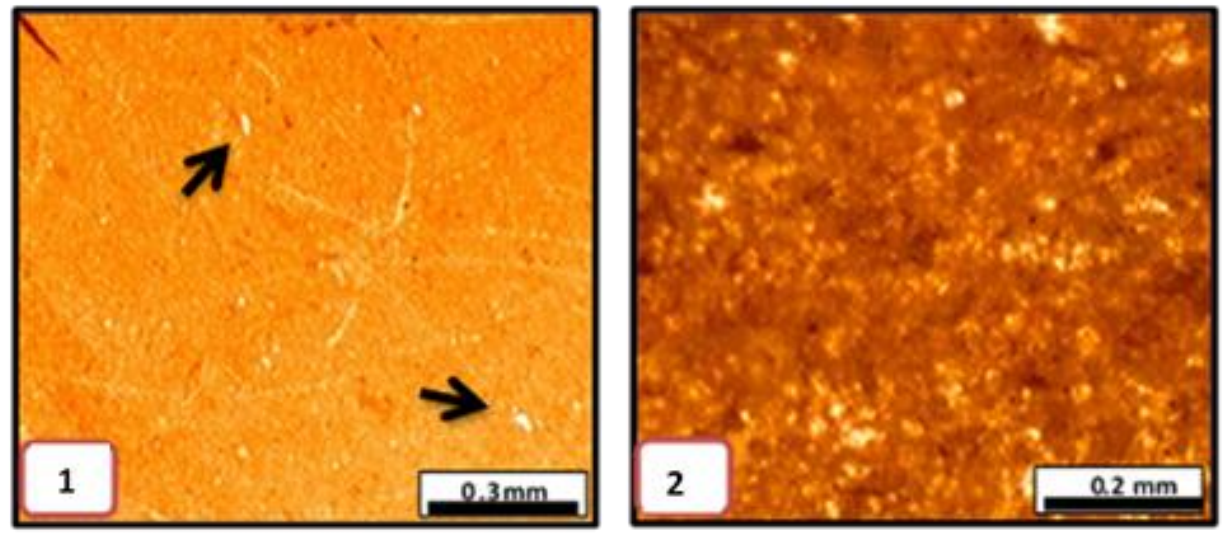

Fig. 9. 1. Aphanotopic texture with fenestrae porosity, Dolomite facies S2, sample n. A14; 2. Micro suture mosaic texture, Dolomite facies S2, sample n. A16
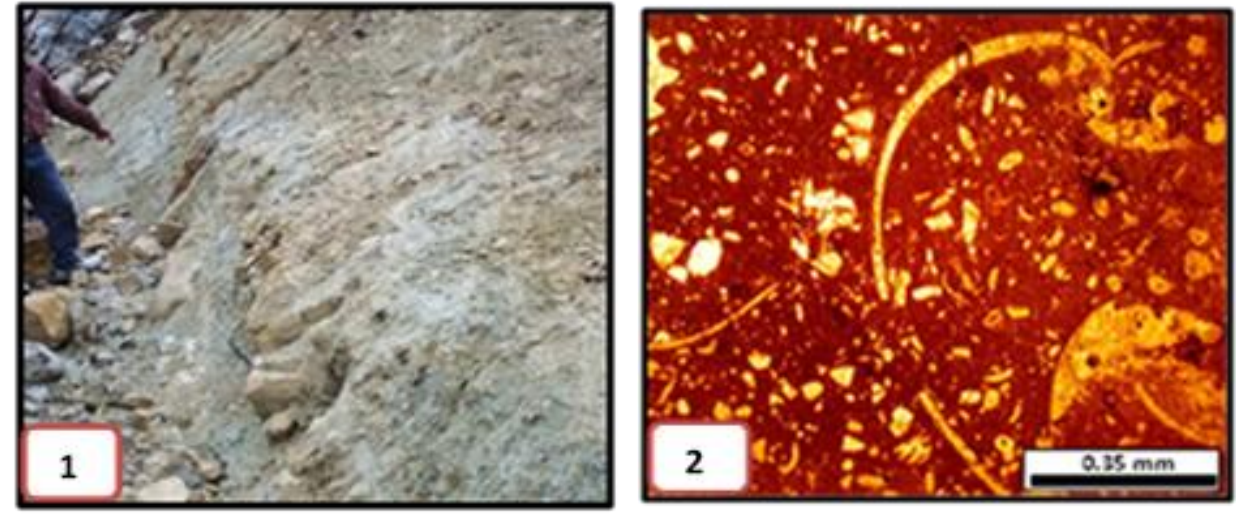

Fig. 10. 1) Marl lithofacies S3; 2) Bivalvia bioclast, Marl lithofacies S3, sample n. A33 


\section{Biostratigraphy}

A few assemblages of benthic foraminifera, as well as echinoderm, gastropods, green algae, and bioclasts, were distinguished in the studied section. The identified benthic foraminiferal assemblages are well to moderately preserved. The identification is based mainly on Banner and Highton (1990), Husinec and Sokač (2006), Husinec, et al. (2009), Krajewski and Olszewska (2007), BouDagher-Fadel (2008), Olszewska (2010) and Jamalian et al. (2011). Ten species belonging to six genera and six families were recognized, these are: Everticyclammina kelleri (Henson, 1948), Everticyclammina greigi, (Henson, 1948), Everticyclammina sp., Pseudocyclammina lituus Yokoyama, 1890, Pseudocyclammina sp., Istriloculina eliptica, Istriloculina sp., Cuneolina sp., Lenticulina sp., and Scythiloculina sp. (Fig. 9). The identified foraminiferal assemblages in the studied rocks (Fig. 11) can be subdivided into two biozones according to the coloration with the other regions in the world (Fig. 12)., these biozones are;

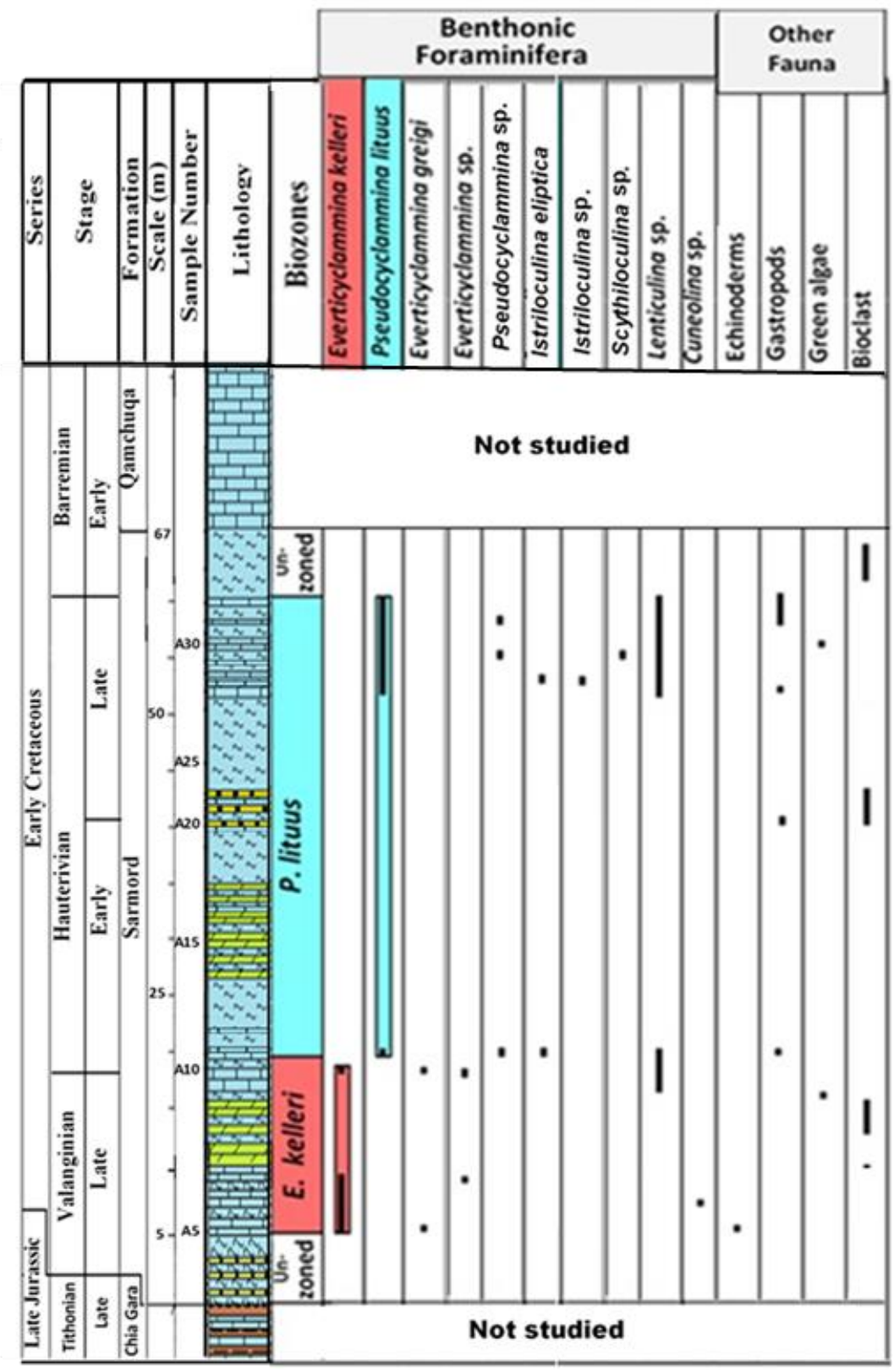

Fig. 11. Stratigraphic column of the Sarmord Formation showing Benthonic Foraminifera ranges and its biostratigraphic zonation 


\subsection{Everticyclammina kelleri Assemblage Zone}

Definition: Assemblage Zone of the index species Everticyclammina kelleri (Henson) associated with other species of benthonic foraminifera (Everticyclammina greigi (Henson), Everticyclammina sp. Lenticulina sp. and Cuneolina sp.), in addition to some gastropods, echinoderms and green algae.

Age: Late Valanginian.

Boundaries: The lower boundary is marked by the first appearance of index species Everticyclammina kelleri (Henson), associated with other species. Whereas its upper boundary is determined by the disappearance of these species.

Thickness: $14 \mathrm{~m}$ represented by samples (A5-A10).

Correlation and age determination: The present zone is equivalent to the Everticyclammina kelleri zone of Chatton \& Hart (1960) in Iraq, and lower part of Pseudocyclammina lituus of Sampo (1969) in Iran, while it is correlative to the Lituola kelleri zone of B. P. \& Idemitsu (1990), and Cyclammina gregi zone of Al- Eisa (1997) in Iraq of Late Valanginian age.

\begin{tabular}{|c|c|c|c|c|c|c|}
\hline \multicolumn{2}{|c|}{ Stage } & Chatton \& Hart, & Sampo, 1969 & B. P. \& Idemitsu & Al- Eisa, 1997 & Present Study \\
\hline ט.: & : & Choffatella decipiens & Dictyoconus arabicus & & Choffatella decipiens & Un zoned area \\
\hline 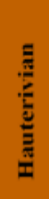 & בัּ & $\begin{array}{c}\text { Pseudocyclammina } \\
\text { lituus }\end{array}$ & $\begin{array}{c}\text { Pseudocyclammina } \\
\text { lituus }\end{array}$ & $\begin{array}{l}\text { Choffatella } \\
\text { decipiens }\end{array}$ & $\begin{array}{c}\text { Pseudocyclammina } \\
\text { lituus }\end{array}$ & $\begin{array}{c}\text { Pseudocyclammina } \\
\text { lituus }\end{array}$ \\
\hline 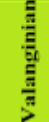 & נ̆ & $\begin{array}{c}\text { Pseudocyclammina } \\
\text { kelleri }\end{array}$ & & Lituola kelleri & Cyclammina gregi & $\begin{array}{c}\text { Pseudocyclammina } \\
\text { kelleri }\end{array}$ \\
\hline
\end{tabular}

Fig.12. Correlation chart of Benthonic Foraminifera of the Sarmord Formation zones with other zonal schemes

\section{2. Pseudocyclammina lituus Assemblage Zone}

Definition: this zone represents the Assemblage Zone of the index species Pseudocyclammina lituus Yokoyama associated with other species of benthonic foraminifera (Pseudocyclammina sp., Istriloculina eliptica, Istriloculina sp., Lenticulina sp., and Scythiloculina sp.) with some gastropods and green algae.

Age: Early - Late Hauterivian.

Boundaries: The lower boundary of this Zone is marked by the first appearance of index species

Pseudocyclammina lituus Yokoyama, with other associated species. Whereas its upper boundary is determined by the disappearance of these species.

Thickness: $41 \mathrm{~m}$ represented by samples (A11- A33)

Correlation and age determination: This zone is correlated with Pseudocyclammina lituus zone of Chatton \& Hart (1960) in Iraq and the middle-upper part of Pseudocyclammina lituus of Sampo (1969) in Iran of Late Hauterivian age. While it is equivalent to the lower - middle part of the Choffatella decipiens zone of B. P. \& Idemitsu (1990), and Pseudocyclammina lituus zone of Al- Eisa (1997) in Iraq of Early - Late Hauterivian age. 


\section{Discussion of the Depositional Environment}

This study represents the first study of the Sarmord formation within the Amadia area. It must clarify that it is not easy to study the Sarmord Formation due to the dolomitization process which obliterated the original texture and structures of the rocks, in addition to the scarcity of the fauna in it, so any additional study about Sarmord Formation in any section will add valuable information leading to increase the understanding of the depositional environment of this formation and its paleogeographic extensions. Before starting to discuss the current study with other studies, it is necessary to review the most important results of this study; The larger benthic foraminifera are very important tools in determining the sedimentary environment because they are very sensitive to environmental variables (Sari et al., 2008). Furthermore, the larger benthic foraminifera (facies FS1) spread within shallow open marine environments, and the prevalence of Everticyclammina and Pseudocyclammina reflects open platform areas (Shebl and Al-Sharhan, 2000 and Krobicki and Olszewska, 2005), and it is matched to SMF 8 and 9 within FZ. 7 (Wilson, 1975; Flugel, 2004). On the other hand, the intercalating of thin marl beds within the dolostone beds (facies FS2), indicates a relatively calm environment affected by fluctuating climate changes, aformationnd this is available within shallow intertidal environments (Johnson and Reynolds, 1986). Add to that, the aphanotopic texture in the same facies (FS2) is produced from dolomitization of lime mudstone rocks that are usually deposited in areas of intertidal flats (Randazzo and Zachos, 1984). The prevalence of aphanotopic texture and fenestrae porosity, that are empty or filled by gypsum with the scarcity of allochems reflects its origins within environments of a high carbon production and high salinity that are difficult to live in, and this is represented by the supratidal environments and carbonate tidal flats with weak contact with the open sea (Shinn, 1983 and Flugel, 2004). Accordingly, this microfacies can be compared to the SMF: 23 within the FZ: 9 (Wilson, 1975; Flugel, 2004). The presence of conglomerate lithofacies (FS4), which consists of three pale yellow beds, suggested that it has been deposited within coastal environments and represented the beginning of a new sedimentary cycle (Boggs, 2006 and Nichols, 2009). Finally, the propagation of Mollusca (Bivalvia and Gastropod) (facies FS3) reflects shallow marine environments within coastal areas, and the occurrence of bivalves bioclast refers to the intertidal environment (Kumar \& Seraswati, 1997).

The results of the present study can be compared with other studies of the Sarmord Formation within the Gara and North Zakho regions, due to its proximity to the current study area. Al Abbasi (2017) studied the Sarmord Formation deposits within the Gara region, and assigned it to late Barremian - early Aptian age, in addition to characterizing the facies of Lime mudstone microfacies, Fossiliferous lime wackestone microfacies and Dolomite Lithofacies, which reflect a shallow marine and tidal flat environment, and this is consistent with the results of the current study. As for the difference in age between the two regions, according to Al Abbasi (2017), the Gara region experienced marine flooding at an early stage compared to the Amadia region, which witnessed a noticeable rising than the rest of the surrounding areas during that time. Besides, he pointed out that when the Sarmord Formation was deposited within the Amadia region, the Gara region received deep marine facies of Balambo Formation, which did not witness a shallowing in its facies until late Barremian through the deposition of the Sarmord Formation. By contrast, Basher and Al-Samarraie (2012), studied the Sarmord Formation in north Zakho area and indicated that the formation environment represents deep shelf margin in terms of diagnosing deep facies that contain Radiolaria and Cephalopod fossils, and this is not recorded in the current study. This indicates that Sarmord Formation in north Zakho was deposited within marine areas deeper than the studied area. Since the current study represents the first study of Sarmord Formation in the Amadia area, we recommend relying on it as a basic study of the formation within this region. Besides, detailed stratigraphical and sedimentological studies are highly recommended for future works of other sections close to the study area, especially in north Zakho, in order to developing a comprehensive view for the depositional environment of the Sarmord Formation. 


\section{Conclusions}

According to the distribution of the benthonic foraminifera assemblage, the Sarmord Formation is subdivided into two biozones, these biozones are (Pseudocyclammina lituus Assemblage Zone and Everticyclammina kelleri Assemblage Zone) which assigned Late Valanginian to Late Hauterivian age. The characteristic feature of the studied facies reflects that the Sarmord Formation in Maten anticline was deposited from carbonate tidal flat to shallow open marine environments.

\section{Acknowledgements}

The authors are grateful to the Editor in Chief Prof. Dr. Salih M. Awadh, the Secretary of Journal Mr. Samir R. Hijab, and the Technical Editors for their great efforts and valuable comments.

\section{References}

Ahmed, S.H. \& Barrier, É. and Müller, C., 2016, Basin evolution model during cretaceous in the northeastern of Arabian plate in Kurdistan region, Arabian Journal Geoscience, 9, 645.

Al-Abbasi, M. W., 2017. Sedimentological and Stratigraphical study of the Late Jurassic - Early Cretaceous (Tithonian - Aptian) Successions from Selected Areas - North Iraq. Unpublished Ph.D. Thesis University of Mosul. 216P.

Banner, F. T. and Highton, J., 1990. On Everticyclammina Redmond (Foraminifera) especially E. kelleri (Henson). Journal of Micropaleontology, 9, 1-14.

Basher, W. Ph. and Al-Samarraie, B. A., 2012. Petrographic study of the Sarmord Formation in North Zakho, NW Iraq. Iraqi Bulletin of Geology and Mining, .8 (2), 45- 63.

Bellen, R. C., Dunnington, H.V., Wetzel, R., and Morton, D.M., 1959. Laxique statigraphique international Asia, Fascicule, 10a, Iraq, Paris, 333 pp.

Boggs, S. J., 2006. Principles of sedimentology and stratigraphy.4th ed., Pearson Prentice-Hall, Upper Saddle River, New Jersey, 662 pp.

BouDagher-Fadel, M. K., 2008. Evolution and geological significance of larger benthic foraminifera developments in Palaeontology and Stratigraphy 21, Elsevier, Amsterdam, 540 pp.

British Petroleum and Idemitsu, 1990. Basin analysis and prospectivity. Vol. 1, Regional Geology and Stratigraphy. London

Chatton, M. and Hart, E., 1960. Revision of the Tithonian to Albian stratigraphy of Iraq, North Oil Company, 62 2379.

Ditmar, V., 1971. Geological conditions and hydrocarbon prospects of the Republic of Iraq (Northern and Central parts), North Oil Company, Iraq.

Flugel, E., 2004. Microfacies of carbonate rocks, analysis, interpretation and application, Springer, Berlin, 976 pp.

Husinec, A. and Sokač, B., 2006, Early Cretaceous benthic associations (foraminifera and calcareous algae) of a shallow tropical-water platform environment (Mljet Island, southern Croatia). Cretaceous Research, 27, 418-441.

Husinec, A., Velić, I. and Sokač, B., 2009, Diversity Patterns in Mid Cretaceous benthic foraminifera and Dasycladalean algae of the southern part of the Mesozoic Adriatic Platform, Croatia. SEPM Special Publication, 93, 153-170.

Jamalian, M., Adabi, M. H., Moussavi, M. R., Sadeghi, A., Baghbani, D. and Ariyafar, B., 2011. Facies characteristic and paleoenvironmental reconstruction of the Fahliyan Formation, Lower Cretaceous, in the Kuh-e Siah area, Zagros Basin, southern Iran. Original article, Springer-Verlag, 57,101-122.

Jassim, S. Z. and Buday T., 2006a. Late Tithonian - Early Turonian Megasequence AP8. In Jassim, S. Z. and Goff, C. (eds.), Geology of Iraq, Published by Dolin, Prague and Moravian Museum, Brno, 124-140.

Jassim, S. Z. and Buday T., 2006b. Tectonic Framework. In Jassim, S. Z. and Goff, C. (eds.), Geology of Iraq, Published by Dolin, Prague and Moravian Museum, Brno, 45-55.

Johnson, M. J. and Reynolds, R. C., 1986. Clay mineralogy of Slate -limestone rhythmites in the Scaglia Rossa (Turonian - Eocene), Italian Apennines. Journal of Sedimentary Petrology, 56, 501-509. 
Karim, K.H., Al-Dulaimy, S.I., Ahmad, P.M. and Al-Badrani, O., 2021. Stratigraphy and Nannofossil Biozonation of Sarmord Formation on the Qaywan Anticline in Sulaymaniyah Governorate, Northern Iraq. The Iraqi Geological Journal, 54 (2D), 75-86.

Krajewski, M. and Olszewska, B., 2007. Foraminifera from the Late Jurassic and Early Cretaceous Carbonate platform facies of the southern part of the Crimea Mountains, Southern Ukraine. Annals Society Geology, Poland, 77, 291-311.

Krobicki, M. and Olszewska, B., 2005. Urgonian-type microfossils in exotic pebbles of the Late Cretaceous and Paleogene gravel stones from the Sromowce and Jarmuta formations (Pieniny Klippen Belt, Polish Carpathians). Studia Geologica Polonica, 124, 215-235.

Kumar, A. and Saraswti, P., 1977. Response of larger foraminifera to mixed Carbonate - Siliciclastic environments, Oligocene - Miocene, India, Paleoge. Paleoclimt. Palaeoeco., 136, 53- 65.

Mamaseni, W. J., Naqshabandi, S. F. and Al-Jaboury F. Kh.,2018, Petrophysical properties of the Early Cretaceous Formations in the Shaikhan Oilfield, Northern Iraq, Earth Science Resources Journal, 22 (1),45-52.

Merty Energy Company, 2004. Geological Map of Northern Iraq. Appendix 1.

Nichols, G., 2009. Sedimentology and Stratigraphy, 2nd.ed, Wiley-Blackwell, 419 pp.

Ogg, J. G., Ogg, G. M. and Gradstein, F. M., 2016. A concise geologic time scale. Amsterdam, Netherland, Elsevier, 234 pp.

Olszewska, B., 2010, Microfossils of the Upper Jurassic-Lower Cretaceous Formations of the Lublin Upland (SE. Poland) based on thin section studies. Polish Geological Institute Special Papers, 26, 1-26.

Randazzo, A. F. and Zachos, L. G., 1984, Classification and description of dolomite fabrics of rocks from the Floridian aquifer. Sedimentary Geology, 37,151-162.

Sampo, M., 1969. Microfossils of the Zagros area, Southwestern Iran, (from Pre- Permian- Miocene). Journal Brill, Leiden, 1-102.

Sari, B., Sari, K. and Ozer, S., 2008. Benthonic foraminiferal biostratigraphy of the Upper Cretaceous (Middle Cenomanian-Coniacian) sequences of the Bey Daglaria carbonate platform, Western Taurides, Turkey. Turkey Journal of Earth Science, 14,78-99.

Shebl, H. T. and Al-Sharhan, A., 2000. Microfacies analysis of Berriasian -Hauterivian carbonate, Central Saudi Arabia. SEPM, (Society for Sedimentary Geology), Special Publication, 69,115-127.

Wilson, J. L., 1975. Carbonate facies in geologic history, Springer - Verlag, Berlin, 471 pp. 